\title{
Organizational Culture, Work Ethics and Organizational Performance (Case Study in the Regional Secretariat of Malaka Regency)
}

\author{
Laurens Bere M.N.B.C. Neolaka Ajis Salim Adang Djaha \\ Master's Program in Administrative Science, Postgraduate Programs, Universitas Nusa Cendana, Nusa Tenggara \\ Timur, Indonesia
}

\begin{abstract}
The purpose of this paper is to describe employee organizational culture and work ethic in an endeavor to improve organizational performance. The assumption built was organizational culture becoming the driving factor of work ethic. In turn, organizational culture and work ethic are capable to influence organizational performance. This research utilized a qualitative approach and case study research. The research was conducted at the Regional Secretariat of the Malaka Regency, East Nusa Tenggara Province. The focus of this research was; (1) Organizational culture; values developed in the organization and are the behaviors of the members of the organization. (2) Work Ethic; the employee's ability to self-actualize in achieving goals as reflected through work spirit. (3) Performance; the work or achievement shown by employees. The research informants were determined through purposive technique. Data collection techniques used were interviews, documentation, and observation. The research results exhibited that the organizational culture in the Regional Secretariat of Malaka Regency was influenced by several factors including Workload, Human Resources, Organizational Structure, Relations of Power, and Wages. The work ethic in the Regional Secretariat of Malaka Regency is influenced by organizational culture and organizational climate. Organizational climate is influenced by several factors including Workplace Conditions, Organization / Leadership Trust, Organizational / Leadership Rewards, Work Associates, Leadership Character / Leadership Style, Organizational Physical Environment, and Assessment of Others. In addition, the Regional Secretariat of the Malaka Regency performance was influenced by the work ethic. The work ethic itself is influenced by organizational culture and organizational climate. Higher response to existing factors in the organizational culture and organizational climate indicates higher employee's work ethic which would improve performance. On the contrary, lower response to existing factor in organizational culture and organizational climate indicates lower work ethic which would reduce performance.
\end{abstract}

Keyword: Organizational Culture, Work Ethic, Performance, Organization

DOI: $10.7176 / \mathrm{DCS} / 9-11-01$

Publication date: November $30^{\text {th }} 2019$

\section{BACKGROUND OF THE STUDY}

Each individual possesses different characteristics. These characteristics enabled people to recognize and acknowledge each individual's behavior. Similar to human beings, organizations possess characteristics. These qualities allowed the masses to determine the characteristics of an organization. This trait is known as organizational culture. Each ethnic group culture possesses a system of values and norms in regulating members and outsiders. Therefore, the organization possesses a culture that governs how its members act.

One external factor that affects employee performance is organizational culture. Organizational culture is the values that develop in an organization. These values are used to direct the behavior of members of the organization (Soedjono, 2005). Employee behavior is influenced by the work environment formed through organizational culture. In turn, organizational culture is expected to improve employee performance. Organizational culture is a pattern of basic assumptions that are found, created, or developed by a particular group with the intention that the organization can overcome problems due to external adaptation. The organization internal integrity needs to be taught and applied to new members as the proper manner of understanding, thinking, and socializing process (Scain in Lako, 2004).

Furthermore, the work environment is no less important in improving employee performance. Therefore the organization must provide an adequate work environment such as the physical environment. It included a comfortable office layout, clean environment, good airflow, color, adequate lighting, and comfortable music. The non-physical environment includes employee work atmosphere, employee welfare, relationships between fellow employees, relations between employees and leaders, and places of worship. A good work environment can support work implementation, ensuring that employees have a passion to work and improve employee performance (Sedarmayanti, 2001: 31).

The employee ability to develop work ethic is a necessary basic attitude. Their work behavior is based on mental awareness, confidence, and full work commitment. Furthermore, these attitudes and views would provide a work assessment, both high and low ratings. It would display work attitude, both serious and lazy attitude. 
Related to the existence of an employee as part of an organization, the work ethic indicates mobilizing the full potential of the employee as part of the organization to achieve goals (Sutisna, 2012).

In addition, several studies exhibited an influence between work ethic, organizational culture, and employee performance. Saleha (2016), on "The Effect of Work Environment, Work Ethics, and Work Culture on Employee Performance at the Public Highways Department in Central Sulawesi Province". The results exhibited that; (1) The work environment, work ethic, and work culture simultaneously have a significant effect on the employees performance of the Public Highways Department in Central Sulawesi Province. (2) The work environment has a significant effect on the employees performance of the Public Highways Department in Central Sulawesi Province. (3) The work ethic has a significant effect on the employees performance of the Public Highways Department in Central Sulawesi Province. (4) Work culture has a significant effect on the employees performance of the Highways Public Corporation in Central Sulawesi Province.

Previous research and studies have proven existing an influence between work ethic and organizational culture on employee performance. Furthermore, in the Unitary State of the Republic of Indonesia regional government at provincial and regency/city level is known was Regional Secretariat. The Regional Secretariat is the supporting element of the regional government leadership. The Regional Secretariat is led by the Regional Secretary. Regional Secretary in the era of political decentralization or regional autonomy has a very important role in influencing the success of regional autonomy in each region. They are demanded to be "sparring partners" of the regional head. The Regional Secretariat consists of the Provincial Secretary and the Regency / City Secretary.

However, the newly established Malaka Regency in East Nusa Tenggara Province has not exhibited expected performance. This situation is understandable because the Malaka Bureaucracy has just begun to improve itself as initiated by the Regent in the first period. Therefore, Malaka Regent's first leadership period was determined to establish basic values of the organization. Therefore, it was expected to shape organizational culture.

This study aimed to explain and describe: (1) Organizational culture within the Regional Secretariat of Malaka Regency; (2) Work ethic within the Regional Secretariat of Malaka Regency; (3) Organizational performance within the Regional Secretariat of Malaka Regency; (4) Factors / aspects that support and hinder the organizational culture, work ethic, and organizational performance within the Regional Secretariat of Malaka Regency. The benefits of this study consist of theoretical benefits and practical benefits. Theoretical benefits are as follows; (1) As a theoretical study material related to Organizational Work Ethics, Organizational Culture, and Organizational Performance. (2) As a material for future researchers in conducting further research. The practical benefits are as follows: (1) One of the requirements in obtaining a master's degree. (2) As input material and consideration for the regional government to develop better organizational management.

\section{REVIEW OF LITERATURE \\ Organizational Culture}

Glaser et al. (1987) stated that organizational culture is often portrayed in a shared sense. Patterns of beliefs, symbols, rituals, and myths that develop over time and function as the adhesive that holds the organization together. Hofstede (1986: 21) states that culture is a variety of interactions of habit traits that affect groups of people in their environment. According to Beach (1993: 12); Culture is the essence of what is important in organizations such as commands, prohibitions, and activities that regulate the members' behavior. Therefore, culture is a guideline used to carry out organizational activities. Organizational culture is a tool to unite every individual who conducts activities together. Kreitner and Kinicki (1995: 532) suggest that organizational culture is a social adhesive that remembers organization members. For differing characteristics or personalities to be united in organizational strength, it is necessary to have social adhesive. Robbins and Judge (2008) define organizational culture as a system of shared meanings that distinguishes an organization from other organizations. According to Robbins and Judge (2008), organizational culture represents a common perception of the members of the organization.

Organizational culture is manifested in two forms, concrete and abstract. (1) Concrete organizational culture is exhibited through how the members serve consumers, dress, and communicate among superiors, subordinates, and coworkers. (2) Abstract organizational culture is exhibited in plain view. This form is the most difficult part to change because it is on the cognitive side of an organization's value system. The organizational culture forms the organization members' idea about their environment. The idea itself is relatively stable from time to time regardless of constantly changing members. Organizational culture cannot be separated from the general cultural context existing in the society. Based on Kast's understanding (in Robbins, 2003) where organizational culture is a set of shared values and belief systems that interact with members of an organization. Organizational structure and supervision system produce norms of behavior. The organizational culture as part of general culture develops in society within an abstract specific scope. On that basis, understanding the elements and characteristics of organizational culture in an organization is crucial.

\section{Organizational Culture Function}

In organizations, organizational culture has various functions. Kast and Rosenzweig (1985: 954) suggested that culture possess the following functions: 1) Conveying a sense of identity for members of the organization, 2) 
Facilitating commitment to something greater than individual interest, 3) Improving social stability, 4) Providing premises accepted and recognized for decision making. According to Robins (2003) organizational culture has the following functions within an organization: 1) Culture has a role within the determining boundaries, namely creating differences between one organization with another organization. 2) Culture functions to convey a sense of identity to members of the organization. 3) Culture encourages commitments to reach beyond the limits of individual interest. 4) The culture encourages social system stability. Culture is a social bond that helps tie together organizations by providing appropriate standards. 5) Culture forms employee behavior and attitudes.

\section{Organizational Culture Characteristic}

Robbins (2003) exhibited that there are seven main characteristics which, as a whole, are the essence of organizational culture. 1) innovation and risk-taking, namely the extent to which employees are encouraged to be innovative and dare to take risks in the work implementation. 2) Attention to details, which is the extent to which employees are expected to carry out the precision, analysis, and attention to details. 3) Results orientation, which is the extent to which management focuses more on results than on the techniques and processes used to achieve these results. 4) People orientation. The extent to which management decisions consider the effects of these results on people within the organization. 5) Team orientation, which is the extent to which work activities in the organization focuses on the team rather than on individuals. 6) Aggressiveness, which is the extent to which people are aggressive and competitive rather than relaxed. 7) Stability, which is the extent to which the organization's activities emphasize maintaining the status quo in comparison to growth.

\section{Work Ethic}

A person's work ethic is closely related to personality, behavior, and character. Every person has an internal being. The internal being determines the response or reaction to external demands. Internal response to the external demands of work field determines one's work ethic (Siregar, 2000). Ethos was derived from Greek. It indicates character, way of life, one's habits, motivation or moral goals, as well as their world view, that is, the most comprehensive picture, way of acting or ideas about the order. In other words, ethos is an evaluative aspect as a fundamental attitude towards themselves and their world that is reflected in their lives (Khasanah, 2004: 8).

Sinamo's (2011) defines work ethic as a set of positive behaviors rooted in beliefs accompanied by a total commitment to the work paradigm. Harsono \& Santoso (2006) states that work ethic is work motivation based on certain values or norms. This is in accordance with the opinion of Sukriyanto (2000 in Sinamo, 2011 :) which states that the work ethic is a community work motivation. It encourages the community to work better and discover the value of their lives. Work ethic determines human judgment realized in a job activity.

In general, factors influencing work ethic are divided into 2 groups (Djanjendra, 2012), namely: (1) Internal Factors; Someone who has a work ethic can be influenced by the motivation that comes from within or from internal factors. Work ethic is a view and attitude based on values believed by a person. Work ethic is determined by the quality of education, expertise, and skills possessed by each individual to improve human resources. Negative emotions would become problem and reduce performance. It ultimately affects productivity, profitability, performance, job satisfaction, and work morale. In turn, it would reduce the success of the organization to achieve its targets. Negative emotions would affect work ethics. (2) External factors; Culture that has been embedded for a long time in society can influence the individuals' work ethic. The culture includes discipline and mental attitude believed by the local community. People who have an advanced orientation system have a high work ethic. Meanwhile, people who have a conservative community system have a low work ethic.

\section{Work Ethic Indicator}

Salamun et al. (1995 in Sinamo, 2011) suggested indicators that can be used to measure work ethics including: "hard work, discipline, honesty and responsibility, industriousness and perseverance". (1) Hard work is a state of constant work to be able to achieve the goals. An individual can take advantage of optimal time. An individual may sometimes do not recognize the time, distance and difficulties encountered. (2) Discipline is an attitude of respect, obedience, and adherence to the written and unwritten rules. An individual possesses the capability to carry out the rules. They do not avoid receiving sanctions upon violating duties and authority. (3) Honesty is the ability of an employee to carry out their work following predetermined rules. (4) Responsibility is to assume that the work carried out is something that must be done with perseverance and sincerity. (5) Industriousness. The creation of an employee's personal habits to maintain and improve what has been achieved. Being industrious at work means developing positive habits at work and maintain good shape at all times. (6) Perseverance means diligence, persistent, and earnest (working, studying, trying, etc.). Persevering people are people who work regularly, can withstand boredom, and want to learn from mistakes (other people and themselves) in the past.

\section{Performance}

According to Pasolong (2008: 196), performance is exhibited through two aspects, namely employee performance (individual) and organizational performance. Employee performance is the result of individual work in an organization. The organizational performance is the totality of the work achieved by an organization. Employee performance and organizational performance have a very close relationship. The achievement of organizational goals cannot be separated from the resources owned by organizations that run by employees. The individuals play 
an active role in efforts to achieve the goals of the organization.

According to Wirawan (2009: 5), performance is the output produced by the functions or indicators of a job or a profession within a certain time. Mangkunegara (2009: 9), argues employee performance (work performance) is the work of quality and quantity achieved by an employee in carrying out duties in accordance with the respective responsibilities.

\section{Performance Appraisal}

The main purpose of the performance appraisal system is to produce accurate and valid information about the behavior and performance of members of the organization (Simamora, 2006: 343). Performance appraisal is simply interpreted as organizational activities in assessing work that has been carried out by workers/members of the organization (Nawawi, 2006: 322). According to Schuler and Jackson (1997: 3), the focus of performance appraisal is to find out how productive an employee is and whether the individuals can work together or more effectively in the future. It is conducted to ensure employees, organizations and society gain benefits.

According to Anatan and Ellitan (2009: 162), performance appraisal is a process used by leaders to determine whether an employee performs work according to respective duties and responsibilities or not. Performance appraisal is a systematic evaluation of employee work and the potential it can develop. Mangkunegara (2009: 10) concluded that the evaluation/performance evaluation is an assessment carried out systematically to find out the results of employee work and organizational performance. In addition, it is conducted to determine appropriate job training, provide appropriate responsibilities to employees, and as a basis for determining policy in terms of promotion or determination of compensation.

Bernardin and Russel (in Sutrisno, 2011: 179), argued that there is six primary performance that can be used to measure performance (employees), namely: (1) Quality. Is the degree to which the process or results of the implementation of activities close to perfection or near the expected goals. (2) Quantity. Represents the amount generated for example the amount of rupiah, units, and cycles of activities carried out. (3) Timeliness. Is the extent to which an activity is completed at the desired time by taking into account the coordination of outputs and available time. (4) Cost-effectiveness. This is the degree to which the use of organizational resources (human, financial, technological, and material) is maximized to achieve the highest results or reduce losses from each unit of resource use. (5) Need for supervision. Is the degree to which a worker can carry out a work function without requiring the supervision to prevent undesirable actions. (6) Interpersonal impact. Is the level to which the employee maintains self-esteem, good reputation, and cooperation between coworkers and subordinates.

In general, Minner (in Sutrisno, 2011: 172), found four aspects that are used to assess performance, namely: (1) Quality production described the number of errors, time, and accuracy in performing tasks. (2) Quantity produced described the total products or services can be produced. (3) Working time described an employee's absences, delays, and years of service. (4) Cooperation described how individuals will help or hinder the efforts of their coworkers.

Eoh (2001: 36), stated that employee performance can be measured in three aspects, namely: (1) Work quantity. Employee performance is measured by the quantity/volume (in the form of products or services) produced during a certain period. This characterizes efficiency - the ability to do the job correctly (concerning the input-output concept). In other words, the ability of employees to achieve maximum performance according to certain standards. (2) Quality is providing the customer or the following person is a useful process; products/services that suit their respective needs. Quality is also related to market share, businesses that offer highquality services generally have a large market share. Employee performance is measured in terms of quality means pointing to the ability to master the work. (3) Creativity is the ability to create or produce something that brings new characteristics or combining new ideas with old methods into new ones. The essence of creativity is seen in efforts to produce new working method, new ventures, and new products. In terms of creativity, employee performance is measured by the creativity of work implementation. These aspects are used as a basis for assessing employee performance in the organization. It determined whether the employee performance has increased in accordance with the set plan.

\section{Conceptual Framework}

Research conducted by Karauwan, Lengkong, Mintardjo (2015) on "The Effect of a Work Ethic, Organizational Culture, and Workload on the Employee Performance in the South Minahasa Public Works Department". The purpose of this study was to determine the effect of Work Ethic, Organizational Culture, and Workload on Employee Performance in the Public Works Department of South Minahasa Regency. The research employed quantitative research methods and multiple regression analysis. The results of the study exhibited that work ethics, organizational culture, and workload simultaneously had a positive and significant effect on employee performance. Work ethic, organizational culture, and workload partially have a significant influence on the employees performance in the Public Works Department of South Minahasa Regency.

Zulham (2008) on "Analysis of the Influence of Organizational Culture and Work Ethics on Employee Performance at the Faculty of Economics, University of North Sumatra Medan". The purpose of this study was to determine and analyze the influence of organizational culture and work ethic on the employees performance of the 
Faculty of Economics, University of North Sumatra, Medan. The approach used was survey research. This type of research is descriptive quantitative. The nature of the research is explanatory research. The results exhibited that organizational culture and work ethics, significantly affect employee performance simultaneously and partially in Faculty of Economics, University of North Sumatra Medan. Based on previous studies, it exhibited an influence between organizational culture and work ethic on employee performance. Therefore, this study constructed the following a conceptual framework :

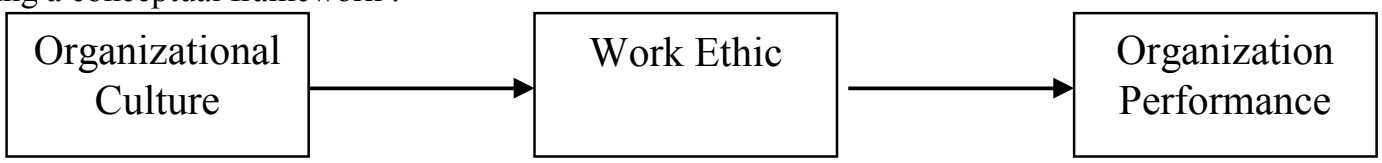

Figure 1. Conceptual Framework

Several previous studies have positioned the organizational culture and work ethic as two independent variables that partially or jointly influence organizational performance. In this study, work ethic is seen as a variable or factor between culture and organizational performance, because the culture is a set of values that do not directly affect organizational performance, but culture must be manifested in the behavior of organizational employees. Behavior controlled by culture influences organizational performance.

Many researchers have conducted research into the relationship of cultural influences and work ethics to quantitative organizational performance. This study used a qualitative approach to describe the influence of culture and work ethic on organizational performance with several cultural cases. Researchers meant to exhibit cultural cases that determine work ethic or morale. Morale determines organizational performance.

This previous research became one of the writer's references in conducting research to ensure the author can enrich the theories used in the research. Based on previous research, the author did not find research with the same title as the author's research title. However, the author raised several previous research as a reference in enriching the study material. The following are previous studies in the form of several journals related to the research.

Table 2.1.1. Previous Research

\begin{tabular}{|c|c|c|c|c|c|c|}
\hline No & $\begin{array}{c}\text { Writer/Title } \\
\text { /Year }\end{array}$ & Focus/Variable & $\begin{array}{l}\text { Research } \\
\text { Method }\end{array}$ & $\begin{array}{l}\text { Result of } \\
\text { Research }\end{array}$ & Similarity & Difference \\
\hline 1 & $\begin{array}{l}\text { Saleha/ Effect } \\
\text { of Work } \\
\text { Environment } \\
\text { Work Ethics } \\
\text { and Work } \\
\text { Culture on } \\
\text { Employee } \\
\text { Performance } \\
\text { in the Public } \\
\text { Highway } \\
\text { Department in } \\
\text { Central } \\
\text { Sulawesi } \\
\text { Province/ } \\
\text { 2016 }\end{array}$ & $\begin{array}{l}\text { - Work } \\
\text { Environment } \\
\text { - Work Ethic } \\
\text { - Work Culture } \\
\text { - Employee } \\
\text { Performance }\end{array}$ & $\begin{array}{l}\text { A } \\
\text { quantitative } \\
\text { approach } \\
\text { using } \\
\text { descriptive } \\
\text { research }\end{array}$ & $\begin{array}{l}\text { The results } \\
\text { exhibited that the } \\
\text { work } \\
\text { environment, } \\
\text { ethics, and work } \\
\text { culture } \\
\text { simultaneously } \\
\text { and partially had a } \\
\text { significant } \\
\text { influence on } \\
\text { employee } \\
\text { performance in the } \\
\text { Public Highways } \\
\text { Department the } \\
\text { Province of } \\
\text { Central Sulawesi }\end{array}$ & $\begin{array}{l}\text { - Researching the } \\
\text { work ethic, } \\
\text { culture, and } \\
\text { employees } \\
\text { performance } \\
\text { - The difference } \\
\text { between } \\
\text { previous } \\
\text { research } \\
\text { variables and } \\
\text { the focus of } \\
\text { current research } \\
\text { is employee } \\
\text { culture and } \\
\text { performance }\end{array}$ & $\begin{array}{l}\text { - } \text { Previous } \\
\text { research assess } \\
\text { influence, } \\
\text { current research } \\
\text { finds new } \\
\text { findings not } \\
\text { merely assess } \\
\text { influence } \\
\text { - Previous } \\
\text { research uses } \\
\text { quantitative. } \\
\text { Current } \\
\text { research uses } \\
\text { qualitative } \\
\text { research } \\
\text { method. }\end{array}$ \\
\hline 2 & $\begin{array}{l}\text { Yuliarti/ The } \\
\text { Effect of Work } \\
\text { Ethics, Work } \\
\text { Discipline, } \\
\text { and } \\
\text { Organizational } \\
\text { Commitment } \\
\text { on Employee } \\
\text { Performance } \\
\text { in the } \\
\text { Morowali } \\
\text { Regency } \\
\text { Housing and } \\
\text { Spatial } \\
\text { Planning } \\
\text { Office } \\
\text { / } 2016\end{array}$ & $\begin{array}{l}\text { Work Ethic } \\
\text { - Work } \\
\text { Discipline } \\
\text { - Organizational } \\
\text { Commitment } \\
\text { - Employee } \\
\text { Performance }\end{array}$ & $\begin{array}{l}\text { A } \\
\text { quantitative } \\
\text { approach } \\
\text { using } \\
\text { explanatory } \\
\text { research }\end{array}$ & $\begin{array}{l}\text { Work ethic, work } \\
\text { discipline, and } \\
\text { organizational } \\
\text { commitment } \\
\text { simultaneously } \\
\text { have a positive } \\
\text { and significant } \\
\text { effect } \\
\text { employee } \\
\text { performance in the } \\
\text { Morowali } \\
\text { Regency Housing } \\
\text { and Spatial } \\
\text { Planning } \\
\text { Department. }\end{array}$ & 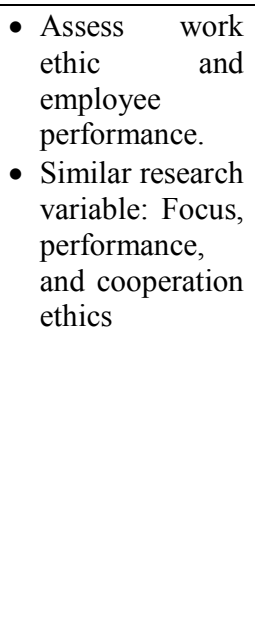 & 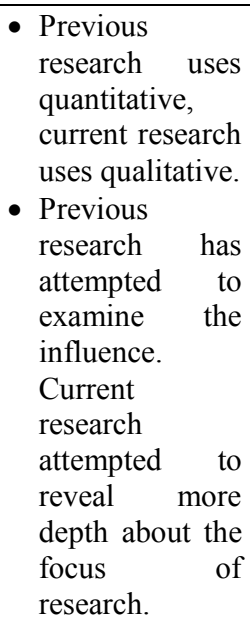 \\
\hline
\end{tabular}




\begin{tabular}{|c|c|c|c|c|c|c|}
\hline 3 & $\begin{array}{l}\text { Timbuleng } \\
\text { dan } \\
\text { Sumarauw/ } \\
\text { Work Ethic, } \\
\text { Work } \\
\text { Discipline, } \\
\text { and } \\
\text { Organizational } \\
\text { Commitment } \\
\text { Influence on } \\
\text { Employee } \\
\text { Performance } \\
\text { at PT Hasjrat } \\
\text { Abadi Manado } \\
\text { Branch/ 2015 }\end{array}$ & $\begin{array}{l}\text { - Work Ethic } \\
\text { - Work } \\
\text { Discipline } \\
\text { - Organizational } \\
\text { Commitment } \\
\text { - Employee } \\
\text { Performance }\end{array}$ & $\begin{array}{l}\text { A } \\
\text { quantitative } \\
\text { approach } \\
\text { using } \\
\text { associative } \\
\text { research }\end{array}$ & $\begin{array}{l}\text { 1. Work Ethics, } \\
\text { Work } \\
\text { Discipline, and } \\
\text { Organizational } \\
\text { Commitment } \\
\text { simultaneously } \\
\text { influence } \\
\text { Employee } \\
\text { Performance at } \\
\text { PT Hasjrat } \\
\text { Abadi Manado } \\
\text { Branch. } \\
\text { 2. Employment } \\
\text { Ethics does not } \\
\text { affect Employee } \\
\text { Performance at } \\
\text { PT Hasjrat } \\
\text { Abadi Manado } \\
\text { Branch. } \\
\text { 3. Work Discipline } \\
\text { influences } \\
\text { Employee } \\
\text { Performance at } \\
\text { PT Hasjrat } \\
\text { Abadi Manado } \\
\text { Branch. }\end{array}$ & $\begin{array}{l}\text { - Assess work } \\
\text { ethics and } \\
\text { employee } \\
\text { performance } \\
\text { - Research } \\
\text { variables and } \\
\text { current research } \\
\text { focus have } \\
\text { common } \\
\text { variable: work } \\
\text { ethic } \\
\text { employee and } \\
\text { performance. }\end{array}$ & 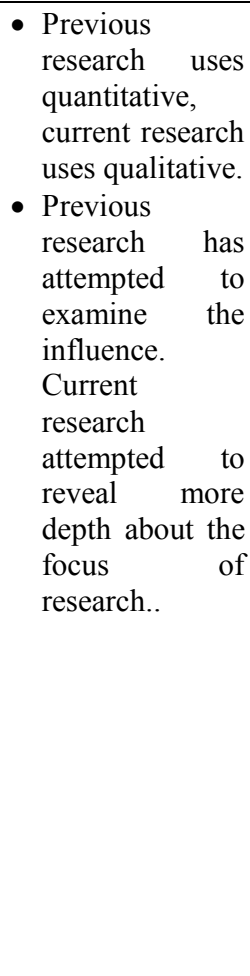 \\
\hline 4 & $\begin{array}{l}\text { Suriansyah/ } \\
\text { The Effect of } \\
\text { Motivation } \\
\text { and Work } \\
\text { Ethics on } \\
\text { Employee } \\
\text { Performance } \\
\text { at the Kota } \\
\text { Baru Regency } \\
\text { Secretariat/ } \\
2015\end{array}$ & $\begin{array}{l}\text { - Motivation } \\
\text { - Work Ethic } \\
\text { - Employee } \\
\text { Performance }\end{array}$ & $\begin{array}{l}\text { Quantitative } \\
\text { approach } \\
\text { with } \\
\text { descriptive } \\
\text { research }\end{array}$ & $\begin{array}{l}\text { Research result } \\
\text { exhibits that } \\
\text { motivation and } \\
\text { work ethic have a } \\
\text { significant } \\
\text { influence on } \\
\text { partial employees } \\
\text { performance at the } \\
\text { Kotabaru District } \\
\text { Secretariat Office } \\
\text { Simultaneously } \\
\text { with work ethic as } \\
\text { the dominant } \\
\text { variable. }\end{array}$ & $\begin{array}{l}\text { - Assess work } \\
\text { ethics and } \\
\text { employee } \\
\text { performance } \\
\text { - Research } \\
\text { variables and } \\
\text { current research } \\
\text { focus have } \\
\text { common } \\
\text { variable: work } \\
\text { ethic } \\
\text { employee and } \\
\text { performance. }\end{array}$ & $\begin{array}{l}\text { - Previous } \\
\text { research uses } \\
\text { quantitative, } \\
\text { current research } \\
\text { uses qualitative. } \\
\text { - Previous } \\
\text { research has } \\
\text { attempted to } \\
\text { examine the } \\
\text { influence. } \\
\text { Current } \\
\text { research } \\
\text { attempted to } \\
\text { reveal more } \\
\text { depth about the } \\
\text { focus } \\
\text { research.. }\end{array}$ \\
\hline
\end{tabular}

Source: Previous research sources are taken from articles in journals that have been included in the References

\section{RESEARCH METHOD}

This research used a qualitative approach case study research. The location of this study was the Regional Secretariat of the Malaka Regency, East Nusa Tenggara Province. The focus of this research was: (1) Organizational culture; the values that develop in the organization and are the behaviors of the members of the organization. (2) Work Ethic; the employee ability to self-actualize in achieving goals reflected in work morale. (3) Performance; the work or achievement exhibited by employees. Informants in this study were determined to utilize the purposive technique. Data collection techniques used were interviews, documentation, and observation. Data analysis employed Miles and Huberman (2007). The validity of the findings/conclusions used Miles and Huberman (1992) method.

\section{FINDING AND DISCUSSION}

The collected data was analyzed with the existing regulations and theoretical framework to formulate the findings of the research results. An individual personality is shaped by the environment. Therefore the individual is encouraged to positive attitudes and behaviors. It must be supported by a recognized norm and guide in conducting the activity. Each individual possesses different characteristics from one another. This characteristic defines a person. Similar to humans beings, organizations possess certain characteristics. These qualities allow the masses 
to define the character of the organization. Each ethnic group culture possesses a system of values and norms in regulating members and outsiders. It can be said that an organization possesses a culture that governs how its members act.

Organizational culture is defined as the values, beliefs, and principles that serve as the basis for an organization's management system, management practices and behaviors that help strengthen these basic principles (Denison, 2000). Peter F Drucker (in Tika, 2009) argues that organizational culture is the principal of solving external and internal problems carried out consistently by a group which is then passed on to new members in various ways as an appropriate way to understand, think and feel about related problems.

Every employee in the organization must have a high commitment to achieving the mission, vision, and goals of the organization. In public sector organizations, the inner bond between employees and the organization can be built from the common mission, vision, and goals of the organization, instead of work ties. society, social status, etc. Should every employee has a strong commitment to providing the best performance for the country and the best service to the community, the performance of the public sector will improve. Organizational culture includes an organizational climate where the environmental influence of the organization affects employee performance in particular and organizational performance in general.

Stringer, as explained by Ruliana (2014: 152), states that organizational climate as an environmental pattern and collection determines the emergence of motivation and focuses on principles that make sense or can be assessed, thus affecting the organization's performance directly. The organizational climate is a term to describe the organizational environment or organizational situation. Organizational climate is related to a set of traits that can be perceived by people in an organization or certain units. Discussion about organizational climate speaks of work environment simultaneously. This issue arises mainly due to organizational activities, carried out consciously or not, are considered influential to organizational behavior (Steers, 1985: 120).

According to Tagiuri and Litwin (in, Wirawan 2009), Organizational climate is a quality of the organization's internal environment. The environment, experienced by members of the organization, influences behavior. It can be described in a set of characteristics or organization characteristics. Stinger (Wirawan, 2009) defines that organizational climate as a collection and environmental patterns that determine the emergence of motivation and focus on perceptions that make sense or can be assessed. It ensured that it has a direct influence on the performance of members of the organization. The organizational climate will then be able to influence the motivation and enthusiasm of the employees who are the basis of the work ethic.

A person's work ethic is closely related to personality, behavior, and character. Every person has an internal being. The internal being determines the response or reaction to external demands. Internal response to the demands of the external factor or work field determines one's work ethic (Siregar, 2000).

Every employee and organization leader is encouraged to possess a high work ethic. This requires hard work and high commitment, otherwise, the organization will find it difficult to develop, and win the competition in capturing market share. Tasmara, (2002) describes the work ethic that should be owned by an employee is the totality of personality and the way an individual expresses, views, believes and gives meaning to a factor which drives an individual to act and achieve optimal charity. It ensures the pattern of the relationship between the individual and fellow man, between humans and other creatures can be intertwined properly.

Based on research results, employee performance that has been classified based on high, medium, low classification was displayed on the results of the study. It was determined based on leadership consideration. The leaders in each section also have performance measurement indicators that are used to measure the performance of their employees. Several indicators used in measuring employee performance in the part of the research locus are; discipline, obedience, loyalty, diligence, quality, timeliness, adhering procedure, honest, hard work. The determination of employee into high, medium, and low classification was determined through the performance appraisal indicators. An employee's performance is set high then the individual tends to meet all the performance appraisal indicators used by the leader. On the other hand, the lower employee performance indicated that the individual fails to meet indicators of performance appraisal.

The fulfillment or ability of employees to achieve performance measurement indicators determined by the leadership is influenced by the work ethic or morale. The higher the work ethic or work morale or motivation increases the fulfillment of the performance appraisal indicators used by the leadership. The results exhibited that the greater or higher the work ethic indicates better performance exhibited through performance evaluation indicators. Conversely, the lower work ethic indicates lower indicators of performance measurement indicators. As a result, it exhibited lower employee performance.

The work ethic itself is influenced by organizational culture and organizational climate. There are several factors in an organizational culture that affect the work ethic of an employee which will also affect the employee and organizational performance. Some of these factors are; Workload, Human Resources, Organizational Structure, Relations of Power, and Wages. The better the employee response to these organizational culture factors, the higher the work ethic will affect performance improvement. On the contrary, the lower the employee's response to the organizational culture factors indicated low work ethic which would decrease employee performance. 
The work ethic is also influenced by the organizational climate which is the interaction between individuals and their environment. Several factors influence the organizational climate which will ultimately affect the work ethic or employee morale. Some of these factors include; Workplace Conditions, Organization / Leadership Trust, Organizational / Leadership Rewards, Work Associates, Leadership Character / Leadership Style, Organizational Physical Environment, Assessment of Others. The better the response to factors in the organizational climate, the higher the employee's work ethic will affect performance improvement. On the contrary, lower employee's response to the factors existing in the organizational climate indicated low work ethic which reduces employee performance.

Based on the theoretical discussion and the results of the research above, the author built a research framework on research results to confirm the results of the study with the existing theoretical framework. The framework of research result is described as follows:

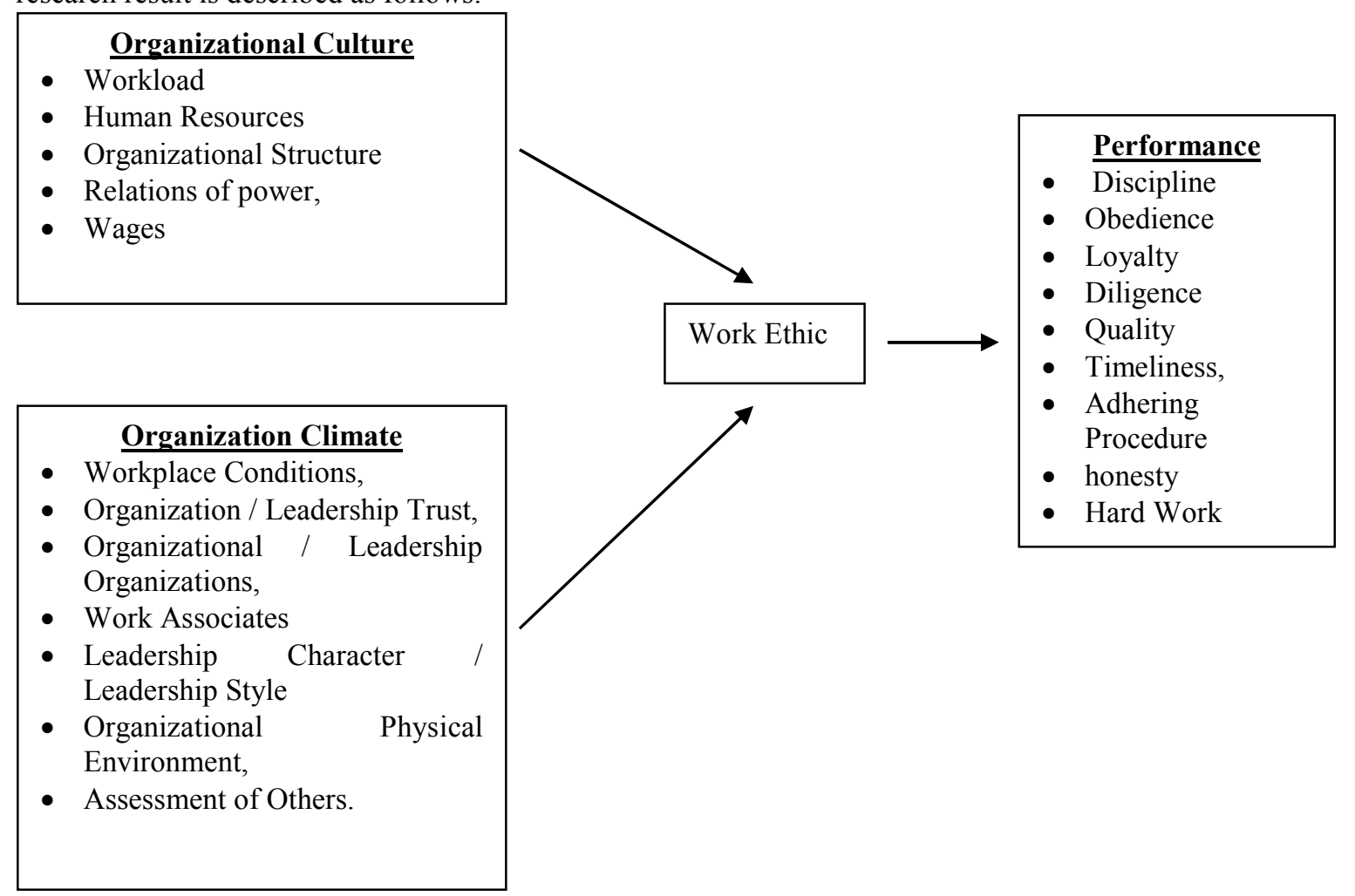

Figure 2. The framework of Research Result

\section{CONCLUSION}

Based on the results of research and discussion, the researcher drew the following conclusion;

1. Organizational culture in the Regional Secretariat of Malaka Regency is influenced by several factors including Workload, Human Resources, Organizational Structure, Relations of Power, and Wages.

2. The work ethic in the Regional Secretariat of Malaka Regency is influenced by the organizational culture and organizational climate. Organizational climate is influenced by several factors including Workplace Conditions, Organization / Leadership Trust, Organizational / Leadership Rewards, Work Associates, Leadership Character / Leadership Style, Organizational Physical Environment, Assessment of Others.

3. The organization performance of the Regional Secretariat of Malaka Regency was influenced by the work ethic. The work ethic itself is influenced by organizational culture and organizational climate. The better the response to the factors existing the organizational culture and organizational climate, the higher the employee's work ethic and performance. On the contrary, the lower employee's response to the factors existing the organizational culture and organizational climate indicates low employee work ethic and performance.

\section{SUGGESTION}

Based on the results of the research, discussion and conclusions that have been described above, the researcher offered several suggestions ts to improve employee performance and organizational performance.

1. There are several employees and sections in Regional Secretariat of Malaka Regency exhibiting varied 
performance. To improve the overall employees performance and the performance of existing parts, the organization needs to pay attention and improve organization members' work ethic or morale.

2. To increase the work ethic or morale, the organization needs to pay attention and improve the factors existing in the organizational culture and organizational climate.

3. The most dominant factor influencing work ethic is coworkers and leadership style. These factors determine organizational climate. Therefore the organization needs to create a good and comfortable organizational climate to increase the work ethic.

\section{REFERENCES}

1. Anatan, Lina dan Ellitan, Lena. 2007. Manajemen Sumber Daya Manusia Dalam Bisnis Modern. Bandung: Alfabeta.

2. Beach, Lee Roy, 1993, Making The Right Decision Organiztional Culture, Vision and Planning.United States of America: Prentice-Hall Inc.

3. Denison and Misra, 1995, "Toward Of Organizational Culture and Effectiveness". Organization Science, Vol.6, No.2, March-April.

4. Djajendra. 2012. Lima Pilar Disiplin Diri (Self Discipline). http://sosbud.kompasi ana. com/2012/11/04/limapilar-kesadaran-diri-506429.html

5. Eoh, Jeny. 2001. Pengaruh Budaya Perusahaan, Gaya Manajemen dan Pengembangan Tim Terhadap Kinerja Karyawan: Studi Kasus di PT. Semen Gresik dan PT. Semen Kupang. Disertasi. Ilmu Administrasi Program Pascasarjana Universitas Indonesia, Jakarta.

6. Glaser, Susan R; Zamanou, Sonia and Hacker Kenneth, 1987, Measuring and Interpreting Organizational Culture. Management Communication Quartely Vol.1 No.2 pp 173-178.

7. Harsono, J dan Santoso, S. 2006. Etos Kerja Pengusaha Muslim Perkotaan di Kota Ponorogo. Jurnal Penelitian Humaniora, Vol. 3, No 1, hal: 56.

8. Hofstede, Geert, 1986, Culture's Consequences, International Differences in Work - Related Values. Sage Publication, Beverly Hills/London/New Delhi.

9. Kast, Fremont E. dan James E. Rosenzweig. 1985. Organization and Management: A Systems and Contingency Approach(Fourth Edition). USA: McGraw-Hill.

10. Khasanah, Uswatun. 2004. Etos Kerja Sarana Menuju Puncak Prestasi. Yogyakarta: HarapanUtama.

11. Karauwan, Raynald; Lengkong, Victor P. K; Mintardjo, Chirtoffel. 2015. Pengaruh Etos Kerja, Budaya Organisasi, Dan Beban Kerja Terhadap Kinerja Pegawai Di Dinas Pekerjaan Umum Minahasa Selatan. Jurnal EMBAVol.3 No.3 Sept. 2015, Hal.1196-1207, ISSN 2303-11.

12. Kreitner, Robert, Kinicki, Angelo, 1995, Organizational Behavior, Third Edition, Printed in The United State of America: Richard D. Irwin Inc.

13. Lako, Mathis \& J, Jackson H. 2004. Human Resource management, $10^{\text {th }}$ edition, Singapore: Cengage learning.

14. Mangkunegara, AA. Anwar Prabu. 2009. Evaluasi Kinerja SDM. Refika Aditama, Bandung.

15. Miles, M.B \& Huberman A.M. 1984.Analisis Data Kualitatif.Terjemahan oleh TjetjepRohendiRohidi. 1992. Penerbit Universitas Indonesia, Jakarta.

16. Miles, Mattew B dan Amichael Huberman. 2007. Analisis Data Kualitatif Buku Sumber tentang MetodeMetode Baru. Terjemahan TjetjepRohendiRohisi. Universitas Indonesia, Jakarta.

17. Nawawi, Hadari. 2006. Kepemimpinan Mengefektifkan Organisasi. Gadjah Mada University Press, Yogyakarta.

18. Pasolong, Harbani. 2008. Kepemimpinan Birokrasi. Alfabeta, Bandung. Rao, T.V, 2002, Penilaian Prestasi Kerja; teori dan praktek, Jakarta : PT.Karya Uni Press.

19. Robbins, Stephen P., 2003, Organizational Behavior, Concept Contropversies and Applications, Prentice Hall Inc. USA.Terjemahan. P.T. Indeks Kelompok Gramedia, Jakarta.

20. Ruliana, Poppy. 2014. Komunikasi Organisasi : Teori dan Studi Kasus. Jakarta : Rajawali Pers.

21. Robbins, Stephen P. dan Timothy A. Judge, 2008, Perilaku Organisasi, Edisi 12 Jilid 1 dan 2, Jakarta: Salemba Empat.

22. Saleha. 2016. Pengaruh Lingkungan Kerja, Etos Kerja Dan Budaya Kerja Terhadap Kinerja Pegawai Pada Dinas Bina Marga Provinsi Sulawesi Tengah. 197 e Jurnal Katalogis, Volume 4 Nomor 3, Maret 2016 hlm 196-203 ISSN: 2302-2019.

23. Schuler, Randall S. dan Jackson, Susan E. 1997. Manajemen Sumber Daya Manusia. Buku 1 dan 2.Terjemahan NurdinSobari dan Dwi Kartini Yahya.Erlangga, Jakarta.

24. Sedarmayanti. 2001. Sumber Daya Manusia dan Produktivtas Kerja. Mandar Maju, Bandung

25. Simamora, Henry. 2006. Manajemem Sumber Daya Manusia. Aditya Media, Yogyakarta.

26. Sinamo, Jansen. 2011. 8 Etos Kerja Profesional. PT Grafika Mardi Yuana, Bogor.

27. Siregar. 2000. Definisi Etos Kerja. Jurnal. (online) http://jurnalsdm.blogspot.com/2010/10/etos-kerjadefinisi-fungsi-dan-cara.html (diakses tanggal 21 Agustus 2018). 
28. Soedjono. 2005. Pengaruh Budaya Organisasi terhadap Kinerja Organisasi dan Kepuasan Kerja Karyawan pada Terminal Penumpang Umum di Surabaya. Jurnal Manajemen dan Kewirausahaan. Vol 7, No. 1, Maret, hal. 23. Surabaya : Universitas Kristen Petra.

29. Steers, Richard. M; Sancches, Carlos J; Ronde and Nardon, Luciana. 2010. Management Across Cultures: Chaleges and Strategis. New York, University Press.

30. Sutisna. 2012. Perilaku Konsumen dan Komunikasi Pemasaran, Edisi Kedua. Remaja Rosdakarya, Bandung.

31. Sutrisno, Edy. 2011. Manajemen Sumber Daya Manusia. Kencana, Jakarta.

32. Tasmara, Toto. 2002. Etos Kerja Pribadi Muslim. Yogyakarta: Dana Bhakti Prima Yasa.

33. Tika, Moh. Pabundu. 2009. Budaya Organisasi dan Peningkatan Kinerja Perusahaan.Jakarta

34. Wirawan. 2009. Evaluasi Kinerja Sumber Daya Manusia, Teori, Aplikasi dan Penelitian. Salemba Empat, Jakarta.

35. Zulham, Muhammad. 2008. Analisis Pengaruh Budaya Organisasi Dan Etos Kerja Terhadap Kinerja Pegawai Fakultas Ekonomi Univeritas Sumatera Utara, Medan. Sekolah Pascasarjana Universitas Sumatera Utara, Medan. 